\title{
TECTONOPHYSICS MAP OF DISCONTINUOUS DEFORMATION OF RYBNIK REGION
}

\author{
MAGDALENA GŁOGOWSKA, ROBERT WARZECHA
}

Główny Instytut Górnictwa, e-mail: mlglogowska@gmail.com; rowarzecha@gmail.com

\begin{abstract}
In this paper, a Tectonophysics map of Rybnik region is presented which is based on the method of determining the direction of the trajectory of the principal stresses in the rock mass and axis orientation of these stresses. This method is used in tectonophysics and is based on the character and parameters of faults. The whole map of Rybnik region encompasses an area of active mines: Rydułtowy-Anna, Marcel, Chwałowice, Jankowice as well as closed ones: Rymer and 1 May of Marcel mine. The paper presents only some fragments of the maps made for the four fault systems and a collective map of tectonophysic, i.e., showing chart areas of compaction for all the systems. The tectonophysics map was made to a scale of 1:20 000. Before the proper work which was the reconstruction of the compaction zone, preparatory work was done. This consisted of updates in 2013 of the tectonics of this area. As a result, tectonic maps were obtained where faults were projected on one level to get their proper azimuth and their inclination. So, a map was made which was used to separate four fault systems arising in similar conditions of stress. Next followed the reconstruction of the main stress fields, which was the cause of faults. On the map there are plotted trajectories showing minimum stress $\left(\sigma_{3}\right)$ and areas of compaction. The maps thus constructed will be used for further studies on the stress spreading and the impact of these areas for geomechanical properties.
\end{abstract}

Key words: compaction areas, tectonophysic, minimum stress trajectories, normal faults

\section{INTRODUCTION}

Diastrophic movements have formed the current tectonic rock massifs revealing, among others, many faults or discontinuities surface. These processes have a significant impact on the geomechanical properties of the rock mass. Particularly important in the study of the rock mass mechanics are the relationships between deformations and the forces causing these deformations and the physics of the processes taking place within the earth (Goszcz [5]). A field of science that addresses it is called the tektonophysics. Using its methods and solutions one can get a lot of valuable information about the orogen. With the help of those methods it is possible to determine the directions of the principal stress trajectories in the rock mass and axis orientation of these stresses.

Generally, it can be said that the tectonic forces caused by diastrophic movements are the reason for the existence of the rock tectonic stresses. In turn, the whole stress create stress tectonic fields (Goszcz [4]). They are usually described by three principal stresses. Depending on the working direction and magnitude of tectonic forces they have a maximum value $\left(\sigma_{1}\right)$, me$\operatorname{dium}\left(\sigma_{2}\right)$ and a minimum $\left(\sigma_{3}\right)$.

The studies performed by Goszcz related to the tectonics of the Upper Silesian Coal Basin in the context of the tectonic stresses have led to important conclusions (Goszcz [3], [4]). The author proved that the sign of principal stress $\sigma_{3}$ can be determined on the basis of the decline of the fault plane. It concerns only normal faults. If the fault is steep, with the slope greater than $65^{\circ}$ it means that it forms with the participation of the horizontal tension. When the fault plane is less than $65^{\circ}$ then it is created under compressive stress, i.e., where $\sigma_{1}$ and $\sigma_{3}$ take a minus value. Analyzing normal faults apart from the sign of minimum stress $\left(\sigma_{3}\right)$ one can approximately reconstruct the trajectory of its course and determine the compressive stress field (Goszcz [3]).

Since the late 1980s issues related to the determination of the compaction zones on the basis of fault parameters and their influence on the mining conditions had been undertaken also in the Central Mining Institute: Bromek et al. [1], Kaziuk [9], Bukowska (ed.) [2].

Tectonic stress, which occurred in the past and led to the creation of faults is an important factor in 
changing the geological and mining conditions of the Carboniferous rock. The presence and character of these disorders are important when choosing an exploitation technology and working system, because they are a serious impediment to mining conduction (Goszcz [3]). The determination of the direction of these trajectories of principal stresses in the rock mass and axis orientation of these stresses is necessary for the study of geodynamic phenomena, such as earthquakes and shock-induced exploitation of mineral deposits.

The present tectonphysical maps of the Rybnik area were made on the basis of the updated maps of tectonic using the above rules.

\section{METHODOLOGY}

The basis for the tectonophysics analysis is the best knowledge about the tectonics of the research area and gathering much of the necessary information for its performance. Knowledge about tectonics of the particular region varies with time and grows with the prog- ress of mining. On the basis of the data obtained, maps were made horizontally with a cross-section of the rock mass along a specified level. In 2012, a current tectonic map of Jastrzębie region was made, and in 2013 of the Rybnik area. The maps were constructed by obtaining a real azimuth and a decline of the fault plane.

Based on the tectonic map of the Rybnik region a detailed analysis of faults was made. As a result, four systems of faults formed in similar stress conditions were distinguished. In this work, there were used the principles worked out by Goszcz [4], [3]) and used also by Kaziuk [8], [9] and Bromek et al. [1]. The basis of the classification of faults to the specific system were:

(a) the occurrence of "complementary" truncation, resulting from the destruction of rocks by truncation. The complementary faults, i.e., corresponding to the principal truncation directions, have the particular importance in the separation of the fault system. Medium stress axis $\sigma_{2}$ sets interpolated edge of the intersection of these faults. The trajectories of minimum stress $\sigma_{3}$ are perpendicular to the axis and the maximum stress axis $\sigma_{1}$ is vertical;

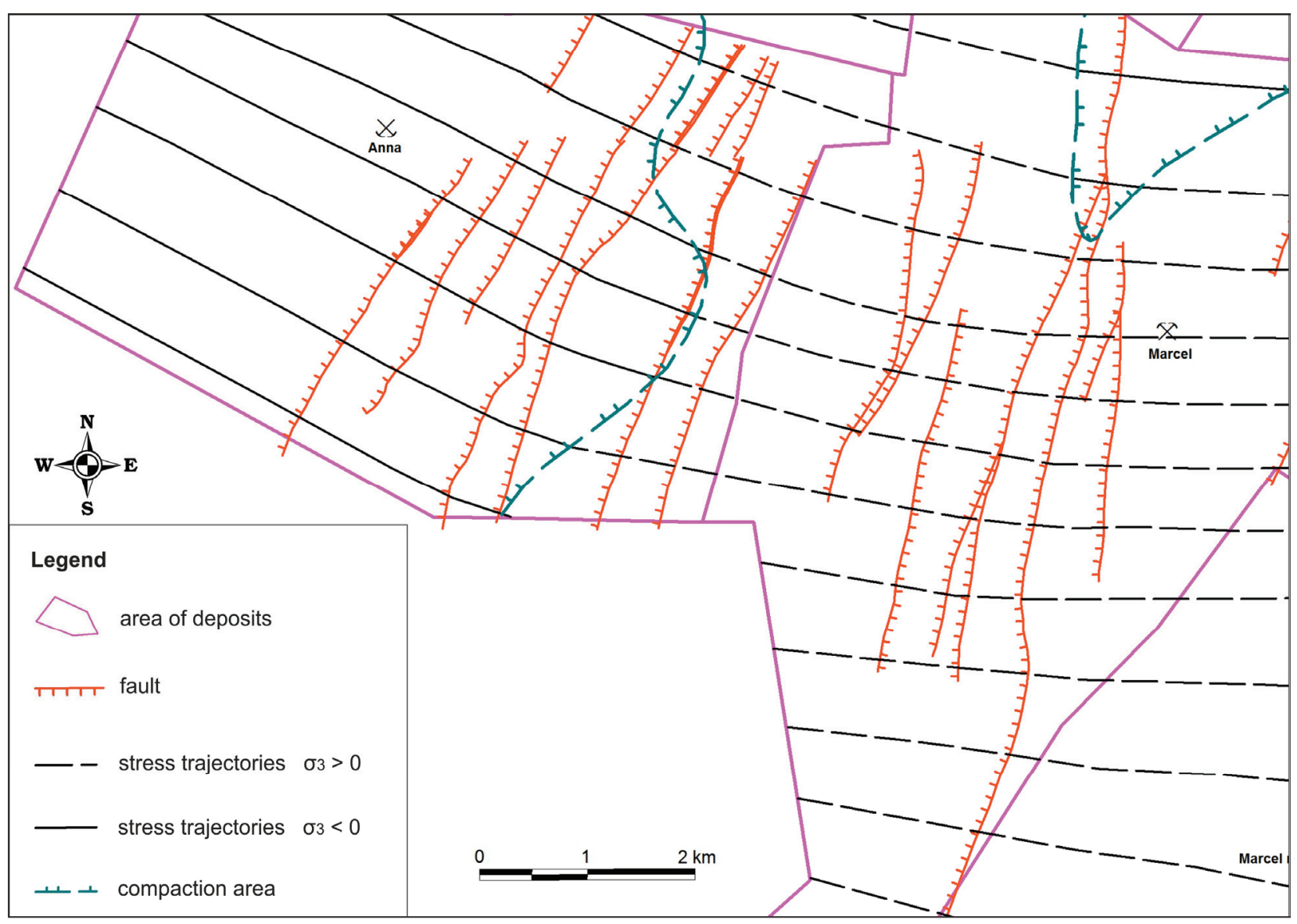

Fig. 1. Fragment of the map showing the tectonics stress field causing fracturing of system 1 
b) similar faults occurring at azimuth. When classifying the faults to a specific system the following azimuth ranges were used:

- System 1 included faults with azimuth N-S,

- System 2 included faults with azimuth SW-NE,

- System 3 included faults with azimuth W-E,

- System 4 included faults with azimuth NW-SE, i.e., faults which were not within the above-mentioned systems.

For each system there was prepared a separate map. In the paper, only fragments of these maps are presented for easier viewing.

In the next step, stress field was reconstructed based on the fault course, accordingly to the rules given in the works of Gzowski [6], Jaroszewski [7] and Goszcz [3]. For this purpose, account was taken of the fault azimuth and the occurrence of "complementary" truncation. Then, the position of the compaction zones for each fault system was presented on a complex map. The trajectory $\sigma_{3}$ was not shown on the map. This was the way of obtaining the tectonophysics map of Rybnik region.

\section{RESULTS}

System 1 of faults in the area of Marcel and Anna deposits is the most developed (Fig. 1). There are 28 faults, over the entire area with a throw from $1.5 \mathrm{~m}$ to $110 \mathrm{~m}$. The decline of the fault planes varies very much and ranges from $28^{\circ}$ to $90^{\circ}$.

System 2 of faults especially clearly distinguishes the area of the Rymer deposit (Fig. 2). Throughout the Rybnik region there are 9 faults with a throw from $10 \mathrm{~m}$ to $220 \mathrm{~m}$. The decline of the fault planes is from $52^{\circ}$ to $81^{\circ}$.

System 3 of faults is the most developed in the Jankowice deposit (Fig. 3). In this area, there are

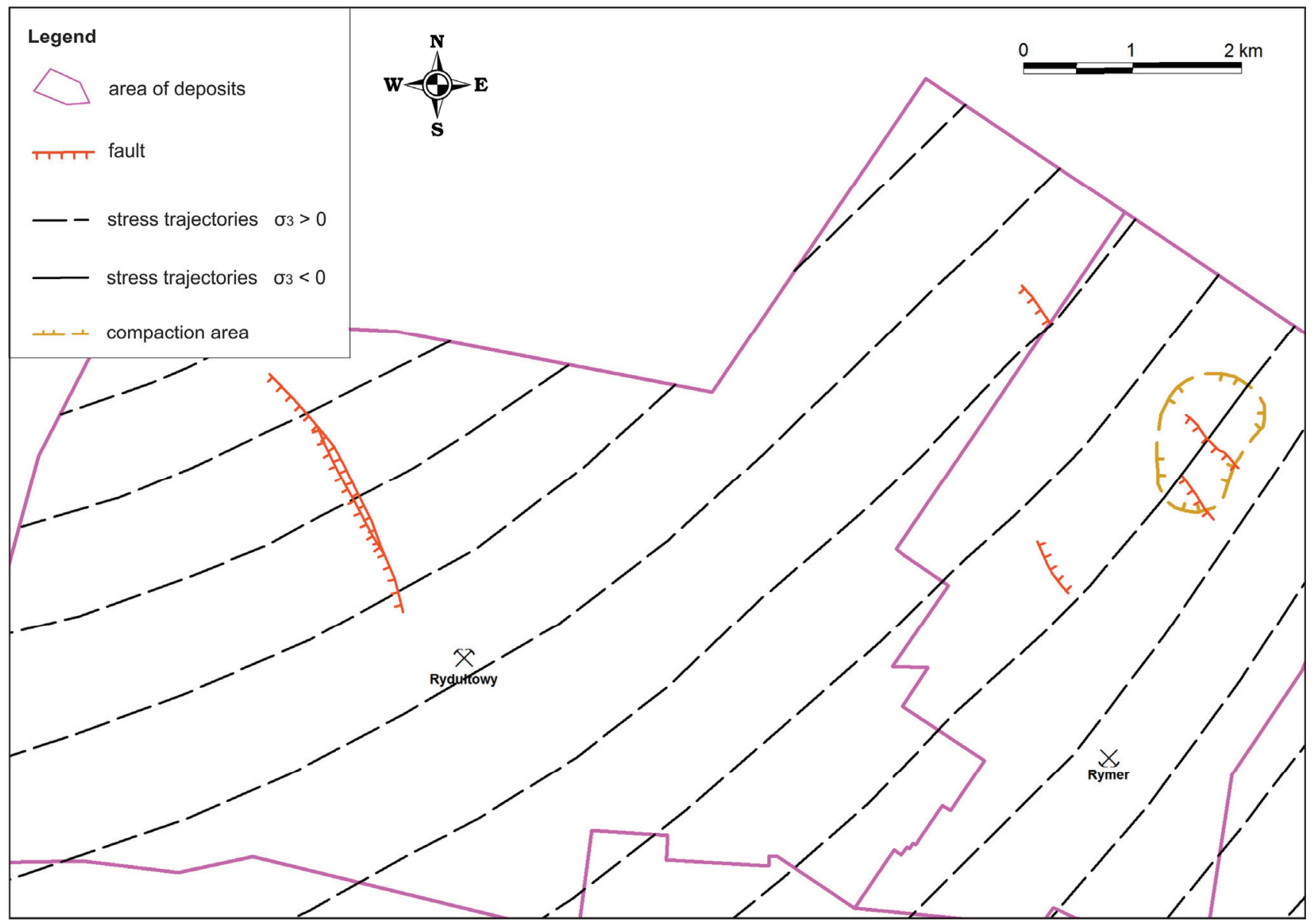

Fig. 2. Fragment of the map showing the tectonics stress field causing fracturing of system 2 


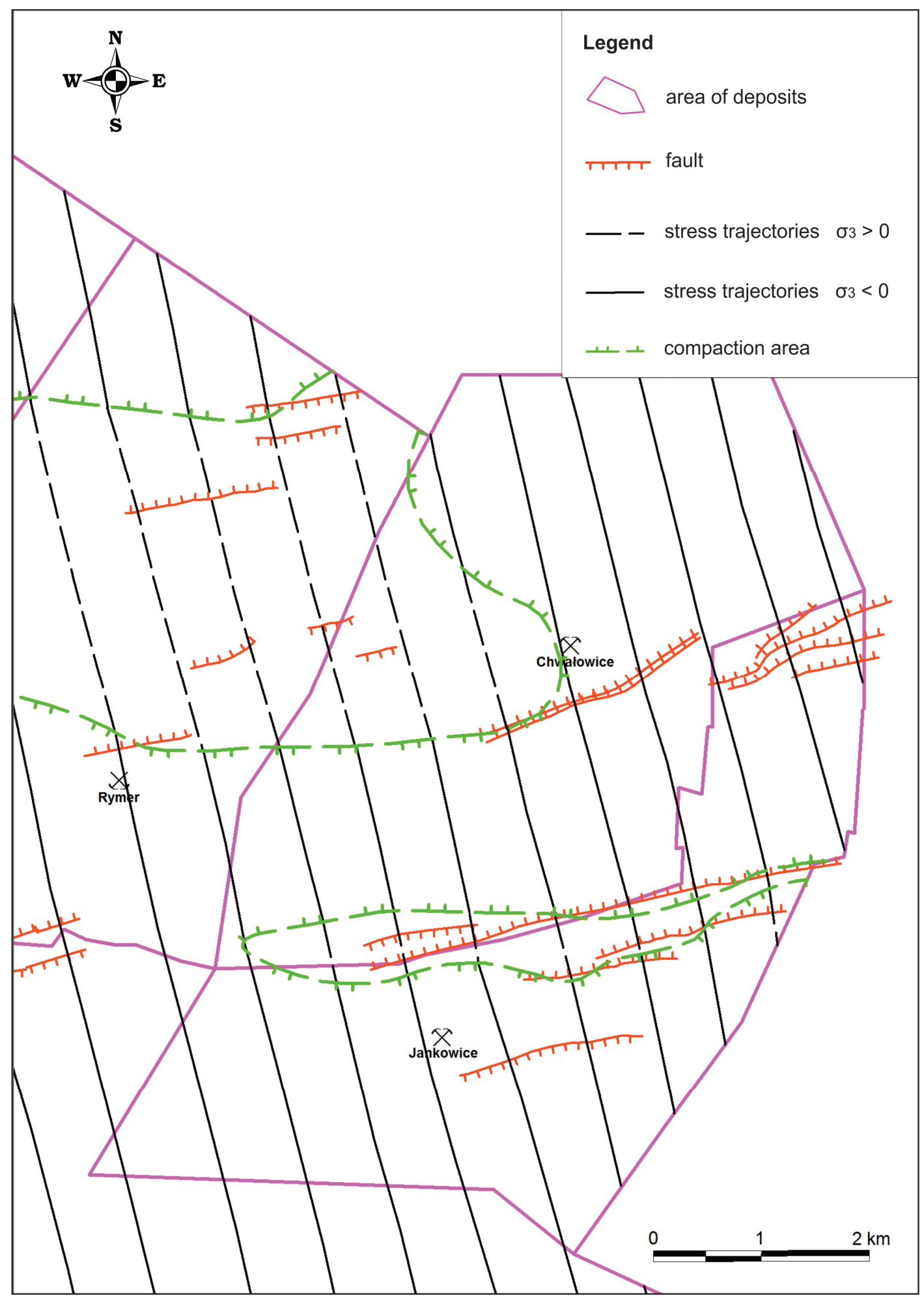

Fig. 3. Fragment of the map showing the tectonics stress field causing fracturing of system 3

28 faults with a throw from 1 to $200 \mathrm{~m}$. The decline of the fault planes is between $30^{\circ}$ and $90^{\circ}$.

System 4 of faults is the most developed in the Rydultowy deposit (Fig. 4). There are faults with a throw from 0.5 to $360 \mathrm{~m}$. The decline of the fault planes is between $49^{\circ}$ and $90^{\circ}$.

The tectonophysical map shown in Fig. 5 has charted areas of compaction for four fault system. It 
may be noted that within the Rybnik region, there occur four types of areas:

1. When versatile compression has occurred in three phases, and in the fourth the minimum stress was a tension.

2. The compression occurred twice and also the tension occurred twice.

3. The compression occurred only once and the tension occurred three times.

4. In all four phases $\sigma_{3}$ there was tension.

The applied areas have contractual division, because one cannot specify the size of the tectonic stress based only on the tectonophysic analysis (Goszcz [3]). On the other hand, to a large extent, it reflects the facts.

Generally, it can be said that the consolidation of the rocks was the largest in the 1st area, where compressive stresses occur three times. In the 2nd and 3rd areas, it was relatively smaller.

In the 4th area, where one of the horizontal tectonic stresses $\sigma_{3}$ in all phases was always tension, carboniferous rock mass is cracked and can be relaxed. In that area, one should expect different geomechanical properties. Also in the 4th area there may occur water hazard (and other hazards as well) because of the greater number of slits in the rock mass. However, these require further research.

\section{SUMMARY}

The Rybnik region is located in the zone of fold tectonics and therefore, the geology is complex and often difficult to interpret. Despite this, or precisely because of this, the area is particularly interesting for research related to the determination of compaction zones.

The article presents only fragments of maps of the Rybnik region for four fault systems, with chart trajectories of the stress $\sigma_{3}$ directions. The directions of principal stress in the rock mass and the orientation of the axis of stress are very important pieces of information necessary for the study of geodynamic phenomena, such as earthquakes and shocks induced by the exploitation of mineral deposits. In addition, the

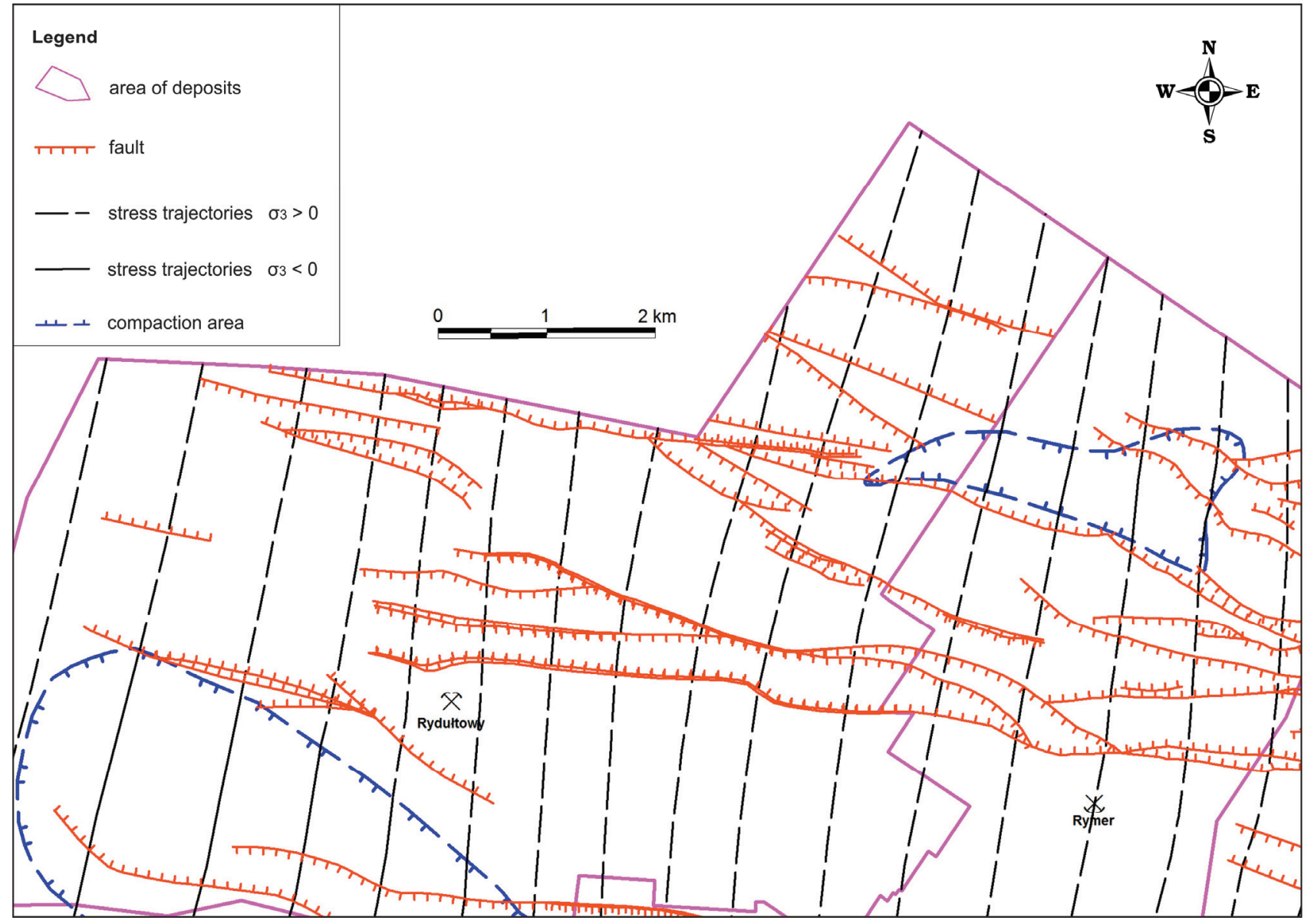

Fig. 4. Fragment of the map showing the tectonics stress field causing fracturing of system 4 


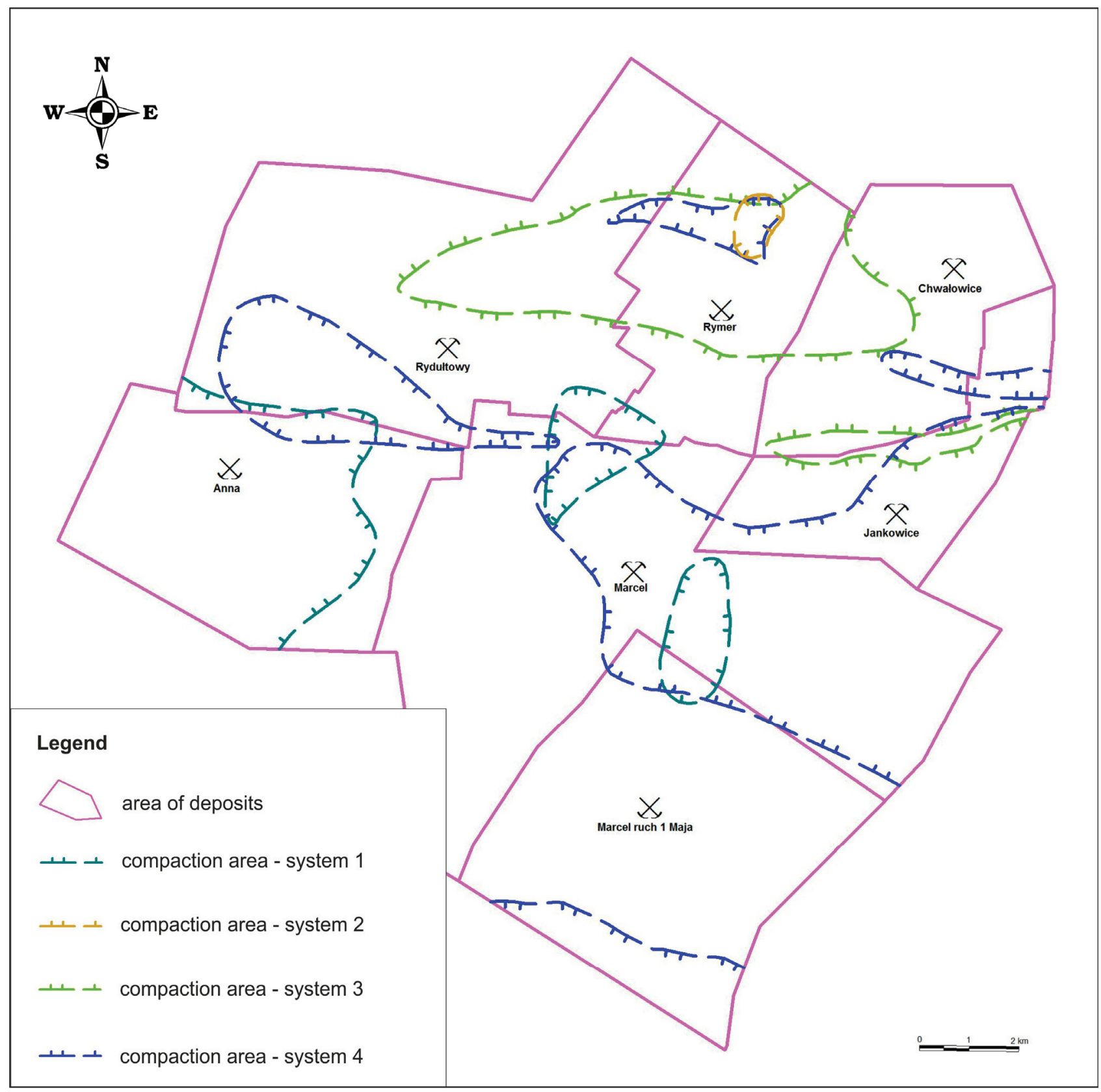

Fig. 5. The compaction areas for the four tectonic fault systems

zones of compaction represent areas where one can expect different geomechanical properties of the rocks, which may have an impact on the mining working.

The tectonophysics map was made to a scale of 1:20000. The whole map of Rybnik region encompasses an area of active mines: Rydułtowy-Anna, Marcel, Chwałowice, Jankowice as well as closed ones: Rymer and as of the 1st May the Marcel mine.

\section{ACKNOWLEDGEMENTS}

The works presented in the paper have been supported by the Polish Ministry of Science and Higher Education, Project No.
11160124-122, entitled "Tectonphysics map of discontinuous deformation of Jastrzębie-Rybnik region".

\section{REFERENCES}

[1] Bromek T., Chudzicka B., GruszKa J., Jureczko J., Kaziuk H., Wawerska B., SzlompeK J., Pukocz Ł., Reinterpretacja mapy tektonofizycznej obszaru GZW, Unpublished Statutory work, Arch. Central Mining Intitute (CMI), 1988.

[2] BukowsKa M. (ed.), Kompleksowa metoda oceny skłonności do tapań górotworu w Górnoślaskim Zagłębiu Weglowym, GIG, Poland, Katowice, 2009.

[3] Goszcz A., Wplyw naprężeń tektonicznych na niektóre własności skat $i$ warunki górnicze $w$ pótnocno-wschodniej części 
Górnośląskiego Zagłębia Węglowego, [in:] Z. Nauk. AGH, Geologia, 27. Wyd. AGH, Poland, Cracow, 1980.

[4] Goszcz A., Mapa tektonofizyczna Zrzeszenia Kopalń Wegla Kamiennego w Bytomiu z wyznaczeniem obszarów skłonnych do tapań, Pol. Tow. Przyjaciół Nauk o Ziemi. Oddział Górnośląski-Sosnowiec. Unpublished work, Arch. Central Mining Intitute (CMI), 1983.

[5] Goszcz A., Elementy mechaniki skat oraz tapania $w$ polskich kopalniach węgla i miedzi, Wyd. Instytutu Gospodarki Surowcami Mineralnymi i Energią PAN, Poland, Cracow, 1999.

[6] GzovskiY M.V., Osnovy tektonofiziki, Wyd. Nauk. Moskva, USSR, Moscow, 1975.
[7] Jaroszewski W., Tektonika uskoków i fałdów, Wydawnictwo Geologiczne, Poland, Warsaw, 1974.

[8] KAzIUK H., Wplyw naprężeń tektonicznych na powstawanie struktur tektonicznych GZW, [in:] Kompleksowa metoda oceny skłonności do tapań górotworu w Górnoślaskim Zagłębiu Weglowym, M. Bukowska (ed.), GIG, Poland, Katowice, 2009.

[9] KazIUK H., Opracowanie mapy tektonofizycznej dla pótnocnej i zachodniej części GZW, Unpublished Statutory work, Arch. CMI, 2003.

[10] Państwowy Instytut Geologiczny - Państwowy Instytut Badawczy. Bazy danych. Web page: Infogeoskarb, 2012, from: http://geoportal.pgi.gov.pl/igs. 